\title{
PROGRAM NO DAY WITHOUT DESINFECTANT DI DAERAH PADAT PENDUDUK SEBAGAI PREVENTIF PENYEBARAN COVID-19 STRAIN DELTA
}

\author{
Mudawamah*, Hendy Mahendra \\ Fakultas Peternakan, Universitas Islam Malang \\ *korespondensi email: mudawamah@unisma.ac.id
}

\begin{abstract}
ABSTRAK
Corona Virus disease (COVID-19) ini terdeteksi pertama kali di Indonesia pada bulan Maret tahun 2020 dan tahun 2021 muncul strain baru yaitu strain Delta yang lebih berbahaya.. Hal ini menyebabkan pemerintah mengeluarkan berbagai kebijakan untuk mengatasi pandemi Covid-19 agar bisa menekan penyebaran virus tersebut. Untuk membantu agar kebijakan pemerintah dapat mencapai tujuannya, maka Universitas Islam Malang (UNISMA) melalui Kandidat Sarjana Mengabdi (KSM-Tematik) kelompok 101 menggulirkan program Bela negara dengan membentuk Relawan UNISMA tanggap pandemi Covid-19. Kegiatan Bela Negara ini dilaksanakan di RT 01 RW 05 Dinoyo Kecamatan Lowokwaru Kota Malang Jawa Timur melalui program No Day Without Desinfectant melalui penyemprotan disenfektan setiap pagi hari Minggu. Kegiatan ini mampu meredakan kekhawatiran masyarakat terhadap covid 19 dan menyadarkan mayarakat yang tidak percaya covid 19 atau menganggap remeh virus corona ini. Masyarakat menjadi paham mengenai perilaku Hidup Bersih dan Sehat (PHBS) dan menerapkan protokol kesehatan yang dianjurkan pemerintah.
\end{abstract}

Kata Kunci: disinfektan; kelompok 101; pandemi covid-19

\section{PENDAHULUAN}

Covid-19 atau biasa yang disebut virus corona adalah penyakit menular yang menular yang disebabkan oleh SARS-CoV-2. Penyakit ini sebelumnya di kenal dengan sebutan 2019 novel coronacirus (2019-CoV) yang berawal dari kota Wuhan Cina (Masruroh \& Hayati, 2021; WHO, 2020). Masing-masing orang memiliki respons yang berbeda terhadap COVID19. Sebagian besar orang yang terpapar virus ini akan mengalami gejala ringan hingga sedang, dan akan pulih tanpa perlu dirawat di rumah sakit. Namun sebagian orang akan mengalami sakit parah dan memerlukan bantuan medis. Corona ini menyerang pada system pernapasan manusia dan pertama kali sekitar tahun 1960 (Larasati \& Haribowo, 2020). Virus ini bisa menyebar dengan cepat melalui kontak fisik hal ini sesuai dengan pendapat Quyumi \& Alimansur (2020). Virus ini menular dengan sangat cepat dan hampir seluruh negara terkena dampak dari virus corona termasuk Indonesia. Presiden Joko Widodo mengumumkan secara resmi kasus pertama Covid-19 di Indonesia pada tanggal 2 Maret 2020.

Setiap negara meminta rakyatnya untuk tetap di rumah, menjaga jarak baik secara fisik (physical distancing) maupun sosial (sosial distancing) bahkan melakukan lockdown (karantina wilayah) untuk mengahambat penyebaran virus corona (Wahidah et al., 2020). Untuk mendukung kebijakan pemerintah mengenai Physical Distancing Menteri Pendidikan dan Kebudayaan (Mendikbud) Nadiem Anwar Makarim menerbitkan surat Edaran Nomor 4 
Tahun 2010 tentang pokok penting yang dibahas adalah proses pembelajaran dilakukan dari rumah secara daring (online) untuk mengurangi kegiatan kontak fisik diluar rumah dan selalu menjaga kebersihan diluar maupun di dalam rumah.

Salah satu upaya yang dilakukan oleh Universitas Islam Malang (UNISMA) untuk mendukung program dari pemerintah adalah dengan mengeluarkan peraturan mengenai Kandidat Sarjana Mengabdi Tematik UNISMA tanggap wabaH Covid-19. Kegiatan ini dilakukan di berbagai wilayah di Indonesia seperti di daerah masing-masing mahasiswa yang ikut berkontribusi dalam kegiatan dalam kegiatan untuk penanganan Covid-19. Kegiatan KSM-Tematik ini diharapkan akan menimbulakan kesadaran masyarakat akan bahaya virus Covid-19 terhadap kesehatan selain itu membuat masyarakat untuk selalu menjaga kebersihan dan masyarakat bisa mematuhi kebijakan pemerintah untuk tetap dirumah.

\section{METODE}

Kegiatan dilakukan pada saat Kandidat Sarjana Mengabdi (KSM) Era Covid-19. Di mulai pada tanggal 2 Agustus dan berakhir tanggal 14 September 2021. Kegiatan dilakukan pada saat Kandidat Sarjana Mengabdi (KSM) Era Covid-19 Tahap 2 yaitu dimulai pada tanggal 1 Februari 2021 dan berakhir tanggal 2 Maret 2021. Kegiatan dimulai dengan penerjunan mahasiswa KSM-Tematik di daerah tempat tinggal masing-masing untuk melaksanakan kegiatan pengabdian masyarakat. Langkah awal adalah setiap mahasiswa membuat jadwal kegiatan secara skruktural untuk dilaksanakan oleh setiap mahasiswa. Kegiatan penyemprotan disinfectant dilaksanakan secara offline dengan memperhatikan protokol kesehatan yang ada (Direktorat Kesehatan Lingkungan, 2020) sedangkan koordinasi kelompok dan dengan Dosen Pembimbing Lapang (DPL) dilakukan secara online via Zoom atau Video Call dan Whatsup grup.

\section{HASIL DAN PEMBAHASAN}

\section{Penyerahan Bahan Disinfektan}

Bahan disinfektan adalah bahan yang digunakan untuk melaksanakan disinfeksi. Perlu diketahui bahwa pengertian disinfeksi dan disinfektan biasanya ditujukan terhadap benda-benda mati seperti lantai, piring, pakaian (Athena et al., 2020; Irianto, 2010). Bantuan ini penting supaya proses penyemprotan desinfentan berjalan lancar dan dapat dilakukan secara rutin. Bahan desinfeksi yang baik bisa menyebar secara merata di permukaan benda mati yang diharapkan dapat menghilangkan virus yang menempel di permukaan benda mati sehingga mengurangi menyebarnya penularan covid-19. Oleh karena itu mahasiswa KSM-Tematik menyerahkan bahan disinfektan sebagaimana Gambar 1.

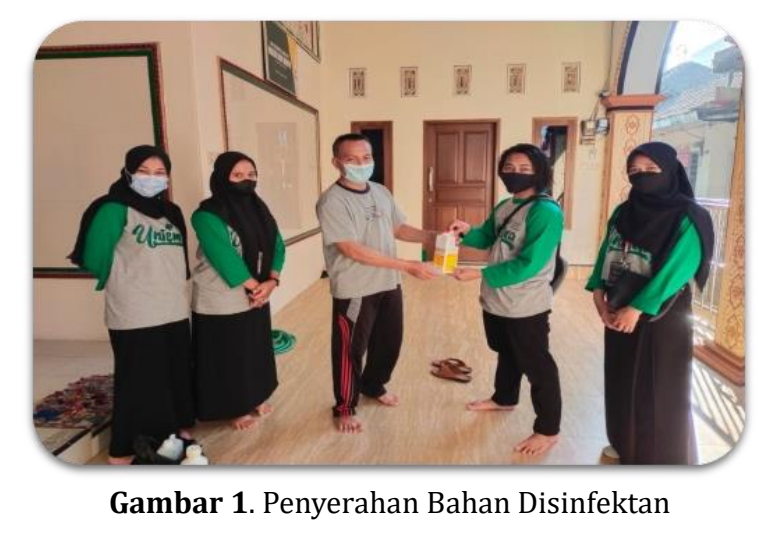




\section{Penyemprotan Disinfektan}

Penyemprotan disinfektan merupakan salah satu cara untuk upaya mengurangi penyebaran virus corona atau covid-19 di lingkungan hunian masyarakat baik dilakukan oleh pemerintah ataupun masyarakat. Manfaat penyemprotan disinfektan adalah membersihkan atau menghilangkan virus, bakteri, dan jamur yang mengganggu kesehatan dari permukaan benda mati. Penyemprotan yang dilakukan diharapkan dapat mengurangi penularan virus corona yang setiap saat bisa bermuatasi.

Penyemprotan disinfektan dilaksanakan mulai dari Balai RT sampai Swalayan secara merata untuk mengurangi atau menghilangkan virus corona dan mengurangi kekhawatiran masyarakat terhadap covid-19 dan menyadarkan pentingnya prokes bagi masyarakat. Prosedur kegiatan ini mengikuti standar protokol dari Direktorat Kesehatan Lingkungan (2020). Kegiatan ini dilaksanakan oleh tim KSM dan dibantu oleh masyarakat sekitar. Kegiatan ini dilakukan dengan berjalan perlahan, sambil melakukan penyemprotan hanya pada benda-benda mati yang paling sering dipegang oleh warga dan tempat yang sering didatangi masyarakat seperti tempat ibadah. Penyemprotan di pemukiman warga (Gambar 2) dan di tempat ibadah atau masjid (Gambar 3).

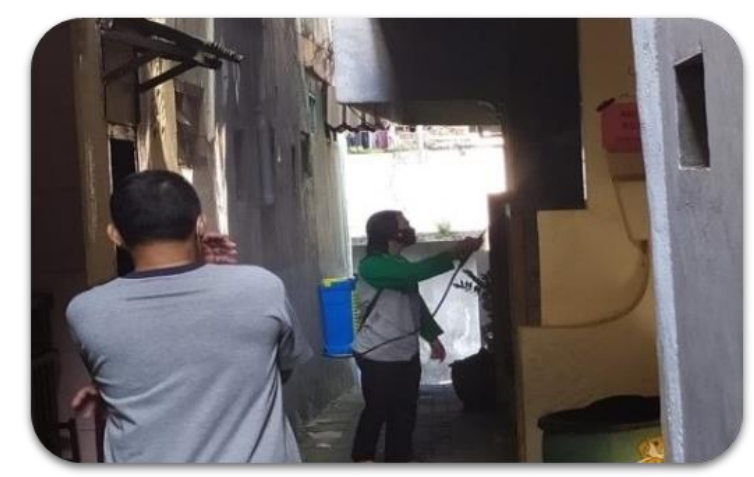

Gambar 2. Penyemprotan di sekitar rumah warga

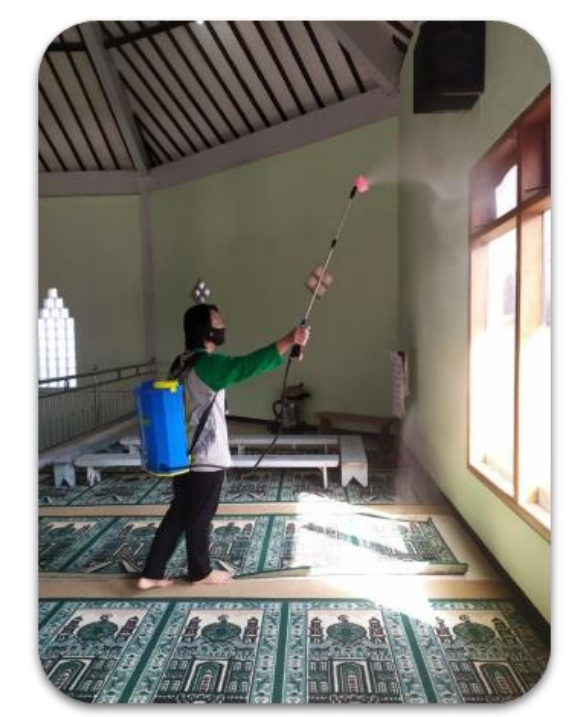

Gambar 3. Penyemprotan di tempat ibadah

Penyemprotan dilakukan secara rutin setiap minggu pagi dengan tujuan untuk meminimalisir virus corona yang menempel di permukaan benda mati, sehingga warga tetap sehat dan dapat melakukan kegiatan sehari-hari dalam masa pandemi covid-19 ini dengan tetap mengikuti protokol kesehatan yang sudah dianjurkan pemerintah. 


\section{KESIMPULAN}

Covid-19 merupakan penyakit yang disebabkan oleh virus corona. Virus ini menyerang sistem pernapasan manusia yang pertama kali di temukan di kota Wuhan, Tiongkok. Penyebaran virus corona ini sangat cepat sehingga menyebabkan Indonesia menetapkan darurat covid-19 berdasarkan keputusan presiden (keppres) Nomor 11 tahun 2020 tentang penerapan kedaruratan kesehatan masyarakat, mengingat jumlah kematian meningkat karena covid-19. Dalam membantu kebijakan pemerintah, KSM-Tematik mengadakan salah satu program yaitu penyemprotan disinfektan yang di adakan setiap hari minggu pagi agar masyarakat terhindar dari covid-19.

Sesuai dengan evaluasi dari program kerja penyemprotan disinfektan, harapannya penyemprotan dilakukan secara berkala setidaknya seminggu sekali agar dapat meningkatkan tingkat keamanan bebas virus covid-19.

\section{DAFTAR RUJUKAN}

Athena, Laelasari, E., \& Puspita, T. (2020). PELAKSANAAN DISINFEKSI DALAM PENCEGAHAN PENULARAN COVID- 19 DAN POTENSI RISIKO TERHADAP KESEHATAN DI INDONESIA. Jurnal Ekologi Kesehatan, 19(1), 1-20. https://doi.org/10.22435/jek.v19i1.3146

Irianto, K. (2010). Mikrobiologi: Menguak Dunia Mikro Organisme (1st ed.). Yrama Widya.

Larasati, A. L., \& Haribowo, C. (2020). Penggunaan Desinfektan dan Antiseptik Pada Pencegahan Penularan Covid-19 di Masyarakat. Majalah Farmasetika, 5(3), 137-145. https://doi.org/10.24198/mfarmasetika.v5i3.27066

Masruroh, \& Hayati, N. (2021). Media poster sebagai sarana edukasi masyarakat dalam upaya pencegahan covid-19. Jurnal Inovasi Hasil Pengabdian Masyarakat (JIPEMAS), 4(36), 169-176. https://doi.org/10.33474/jipemas.v4i2.9207

Quyumi, E., \& Alimansur, M. (2020). Upaya Pencegahan Dengan Kepatuhan Dalam Pencegahan Penularan Covid-19 Pada Relawan Covid. Jph Recode, 4(1), 81-87.

Wahidah, I., Athallah, R., Hartono, N. F. S., Rafqie, M. C. A., \& Septiadi, M. A. (2020). Pandemik COVID-19: Analisis Perencanaan Pemerintah dan Masyarakat dalam Berbagai Upaya Pencegahan. Jurnal Manajemen Dan Organisasi (JMO), 11(3), 179-188. https://doi.org/10.29244/jmo.v11i3.31695

WHO. (2020). Modes of transmission of virus causing COVID-19: implications for IPC precaution recommendations. 